\title{
Effects of an Active Learning Approach on Students' Motivation in an Engineering Course
}

\author{
Chosang Tendhar ${ }^{1}$, Kusum Singh ${ }^{2}$, Brett D. Jones ${ }^{2}$ \\ ${ }^{1}$ Arnold and Marie Schwartz College of Pharmacy and Health Sciences, Long Island University (LIU), Brooklyn, USA \\ ${ }^{2}$ School of Education, Virginia Tech, USA \\ Correspondence: Chosang Tendhar, Arnold and Marie Schwartz College of Pharmacy and Health Sciences, Long Island \\ University (LIU), Brooklyn, USA.
}

Received: December 29, 201

Accepted: January 25, 2019 Online Published: January 31, 2019

doi:10.11114/jets.v7i3.3916

URL: https://doi.org/10.11114/jets.v7i3.3916

\begin{abstract}
Because there are many positive effects of active learning approaches on students' motivation and achievement, some authors have recommended that these approaches be widely implemented. A research-intensive university located in the Mid-Atlantic US was interested in adopting this instructional technique, and therefore, experimented with it. The purpose of this quasi-experimental study was to compare and contrast the effects of an active learning approach on the motivation of students in a treatment and control group. The results of multiple independent sample $t$-tests showed that there were no statistically significant differences between the two groups on several motivation constructs. We provide explanations for the lack of significant differences, as well as discuss limitations and future research.
\end{abstract}

Keywords: music model, engineering identification, engineering career intention, engineering major intention, active learning approach

\section{Introduction}

Recruiting and retaining students in engineering majors, as well as attracting them to engineering fields after their graduations, has been problematic (Rollins, 2011; Weiss, 2009) . Many cognitive variables (e.g., math ability, test scores) and non-cognitive variables (e.g., motivational and personality variables) have been found to predict students' engineering major intentions and career intentions (e.g., Tendhar, Paretti, \& Jones, 2017; Tendhar, Singh, \& Jones, 2018; Major, Holland, \& Oborn, 2012; Jones, Tendhar, \& Paretti, 2015; Carrico \& Tendhar, 2012). In addition, researchers have investigated the effects of different innovative instructional techniques because they have found that a traditional lecture format in classes for STEM (science, technology, engineering, and mathematics) can be detrimental to students' persistence in STEM fields (e.g., Bernold, Spurlin, \& Anson, 2007; Cabrera, Colbeck, \& Terenzini, 1998; Seymour \& Hewitt, 1997). Other issues associated with attrition include a lack of opportunity for questioning, poor teaching, and unresponsive faculty members (Lichtenstein, Loshbaugh, Claar, Bailey, \& Sheppard, 2007; Seymour \& Hewitt, 1997; Strenta, Elliott, Adai, Matier, \& Scott, 1994).

Innovative instructional pedagogies, such as active learning, have been implemented to counter the issue of students' poor experiences in their introductory STEM courses. Active Learning is defined as a technique employed in the classroom that uses student-student and student-facilitator interaction in numerous forms to alter the learning environment from passive to active (Al-Bahi, 2006). This teaching technique was found suitable to meet the requirements of the Accreditation Board of Engineering and Technology's (ABET) Engineering Criteria 2000 (EC2000; Felder \& Brent, 2003). Some of the significant features of the Active Learning strategies are (Bonewell \& Eison, 1991): (1) students are involved in more than passive listening, (2) students are engaged in activities (e.g., reading, discussing, and writing), (3) there is less emphasis placed on information transmission and greater emphasis placed on developing student skills, (4) there is greater emphasis placed on the exploration of attitudes and values, (5) students' motivation is increased (especially for adult learners), (6) students can receive immediate feedback from their instructors, and (7) students are involved in higher order thinking skills (analysis, synthesis, and evaluation).

Problem-based learning (PBL) and peer instruction (PI) are considered as active learning pedagogies because they meet these features. Even though these instructional techniques have different names, they are closely related (Knight, Fulop, Marquez-Magana, \& Tanner, 2008). These instructional techniques have repeatedly been shown to have positive 
influences on students' experiences in their introductory classes (Felder, Forrest, Baker-Ward, Dietz, \& Mohr, 1993; Hoit \& Ohland, 1998; Matusovich Paretti, Jones, \& Brown, 2012; Watkins \& Mazur, 2013) and directly address most of the teaching issues identified by Seymour and Hewitt (1997) and Strenta et al. (1994), such as poor teaching, unresponsive faculty members, and lack of opportunity for questioning. When used appropriately, these approaches can boost students' motivation (Jones, Epler, Mokri, Bryant, \& Paretti, 2013; Matusovich et al., 2012); provide a better understanding of conceptual knowledge (Matusovich et al., 2012; Watkins \& Mazur, 2013); enhance skills in areas such as problem-solving, communication, and teamwork (Knight et al., 2008); and increase the chances that students will persist in STEM fields (Hoit \& Ohland, 1998; Jones et al., 2015; Springer, Stanne, \& Donovan, 1999; Jones, Osborne, Paretti, \& Matusovich, 2014; Watkins \& Mazur, 2013; Tendhar, Paretti, \& Jones, 2017; Tendhar, Singh, \& Jones, 2018).

Because of the potential positive benefits of active learning pedagogies, some have recommend that the federal government encourage educational institutions to embrace active learning approaches on a wider scale (e.g., Gates \& Mirkin, 2012). Given the need to retain students in engineering majors, active learning strategies show promise as a means to engage students in their current class and keep them engaged and identified with the field of engineering (Jones et al., 2013).

The purpose of this study was to investigate effects of an active learning approach on students' motivation-related beliefs, engineering identification, and three engineering-related motivational factors, and students' major and career intentions. We hypothesized, based on the existing literature, that students who participated in an active learning class would have higher level of motivation than their counterparts in a group of students who received more traditional instruction.

\section{Operational Definitions of Motivational and Intentions Variables}

\section{Motivation-Related Beliefs}

The five elements of the MUSIC Model of Academic Motivation are: eMpowerment, Usefulness, Interest, and Caring (Jones, 2009). Empowerment denotes the level of control that students think they have over their learning environment in the course. Usefulness represents students' perceptions of the usefulness of the engineering course for their short- and long-term goals. Success refers to the students' perceptions of their ability to succeed in the engineering course if they invest the required effort. Interest is students' perceptions that the course content and instructional techniques are interesting and enjoyable. And finally, caring is defined as students' perceptions that their instructors in the engineering course cares about their success.

\section{Engineering Identification and Engineering-Related Motivational Factors}

Engineering identification was defined as valuing engineering as part of their identity (Osborne \& Jones, 2011). Engineering Utility is defined as "the usefulness of engineering in terms of reaching one's short- and long-term goals" (Jones et al., 2010, p. 320). Engineering program belonging refers to "the degree to which students perceive that they feel accepted, respected, included, and supported by the engineering students and in the engineering program at the university" (Jones et al., 2014, p. 1343-1344). Jones et al. (2010) described engineering program expectancy as "one's belief in the possibility of his or her success in engineering" (p. 320).

\section{Engineering Major and Career Intentions}

Engineering major intention is students' intention to remain in an engineering major. Engineering career intention refers to students' intention to pursue careers in the field of engineering post-graduation.

\section{Method \\ Procedure}

An active learning approach was implemented in an introductory engineering course at a research-intensive university located in the Mid-Atlantic US. This course had been taught in the past using traditional engineering design (TED). Students were placed in one of two groups: a traditional or pilot (treatment) group. The instructional techique used for the traditional group was that of traditional engineering design (TED), while the instructional technique used for the pilot group had more features of an active learning approach. For example, lecture and workshop sessions for the pilot group drew on research regarding student motivation, meta-cognition, problem-solving, and problem-based learning. Students in both groups had opportunities to interact with each other and their instructors. However, students in the pilot group had a greater amount of group work, which resulted in more interactions. Students in the traditional group spent one workshop session on a team activity, while students in the pilot group engaged in team work during several workshop sessions. 


\section{Participants}

Traditional group. One thousand eighty seven $(1,087)$ and 1,084 students responded to the survey at the beginning and end of the semester, respectively. However, the final analyses were condcuted on 875 and 812 students from the two time periods. In terms of gender, 655 (74.86\%) were male at the beginning of the semester. Fiften students did not report their gender. In terms of race, 602(75.86\%) were white at the beginning of the semester.

Pilot group. Two hundred forty seven (247) and 314 students participated in the survey at the beginning and end of the semester, respectively. However, the final analyses were conducted on 188 and 242 students from the two time periods. In terms of gender, $161(85.6 \%)$ and $206(85.1 \%)$ were male at the beginning and end of the semester, respectively. In terms of race, $144(76.6 \%)$ were White and $177(73.1 \%)$ were White at the beginning and end of the semester, respectively.

\section{Instruments}

We used the MUSIC ${ }^{\circledR}$ Model of Academic Motivation Inventory (Jones, 2016) to assess students' class perceptions of empowerment, usefulness, success, interest, and caring because these constructs have been shown to be related to students' motivation. The five elements (Empowerment, Usefulness, Success, Interest, and Caring) were measured with five $(\alpha=.91)$, five $(\alpha=.96)$, four $(\alpha=.93)$, four $(\alpha=.95)$, and six items $(\alpha=.93)$, respectively. Students' perception of engineering identification was assessed with four-items of Identification with Engineering from Jones et al. (2014; $\alpha=.92)$. Similarly, research participants' perceptions of engineering utility $(\alpha=.97)$, engineering program belonging $(\alpha=.86)$, and engineering program expectancy $(\alpha=.93)$ were measured with six, eight, and five items, respectively. The items used to measure the two intention variables were based on indicator variables used in Jones (2010; two items) and Jones et al. (2012; two items).

\section{Data Analysis}

The Statistical Package for the Social Sciences (SPSS) version 22.0 was used to compute the scale reliabilities, descriptive statistics, and $t$-tests.

\section{Results}

The descriptive statistics and scale reliabilities of the two groups, both at the beginning

and end of the semester, are presented in Tables 1 through 4 . The Cronbach's alphas were consistent with the existing literature. The results of the six independent sample $t$-tests conducted at the beginning of the semester are presented in Table 5. The $t$-tests were conducted to compare scores on six different constructs between students in the traditional and pilot groups at the beginning of the semester. There were no statistical significant differences in scores for students in the traditional and pilot groups on any of the variables except Engineering Program Utility. Eleven independent sample $t$-tests were conducted to compare scores on 11 different constructs (five motivation-related beliefs; four engineering-related motivational factors; and two intention variables) between students in the traditional and pilot groups at the end of the semester and the results of these tests are presented in Table 6. In addition to the six constructs at the beginning of the semester, students' perceptions on the five MUSIC elements were also compared between the two groups at the end of the semester. No statistically significant differences were found between the two groups on any of the 11 variables.

Table 1. Descriptive Statistics and Reliabilities of Traditional Group-Beginning of the Semester

\begin{tabular}{llll}
\hline Variables & Mean & $\begin{array}{l}\text { Standard } \\
\text { Deviation }\end{array}$ & $\begin{array}{l}\text { Cronbach's } \\
\text { Alpha }(\alpha)\end{array}$ \\
Major Intention & 5.35 & 0.77 & .85 \\
Career Intention & 5.08 & 0.85 & .84 \\
Engineering Identification & 5.24 & 0.66 & .84 \\
Engineering Utility & 5.49 & 0.68 & .90 \\
Engineering Program Belonging & 4.97 & 0.62 & .73 \\
Engineering Program Expectancy & 4.83 & 0.69 & .88 \\
\hline
\end{tabular}


Table 2. Descriptive Statistics and Reliabilities of Pilot Group-Beginning of the Semester

\begin{tabular}{lclc}
\hline Variables & Mean & $\begin{array}{l}\text { Standard } \\
\text { Deviation }\end{array}$ & $\begin{array}{l}\text { Cronbach's } \\
\text { Alpha }(\alpha)\end{array}$ \\
Major Intention & & 0.84 & .92 \\
Career Intention & 5.37 & 0.84 & .85 \\
Engineering Identification & 5.08 & 0.73 & .85 \\
Engineering Utility & 5.22 & 0.95 & .95 \\
Engineering Program Belonging & 5.32 & 0.63 & .76 \\
Engineering Program Expectancy & 4.94 & 0.66 & .87
\end{tabular}

Table 3. Descriptive Statistics and Reliabilities of Traditional Group-End of the Semester

\begin{tabular}{llll}
\hline Variables & Mean & Standard Deviation & Cronbach's Alpha $(\alpha)$ \\
\hline Major Intention & 5.39 & 0.89 & .88 \\
Career Intention & 5.13 & 0.93 & .87 \\
Engineering Identification & 5.17 & 0.73 & .86 \\
Engineering Utility & 5.22 & 1.03 & .96 \\
Engineering Program Belonging & 4.90 & 0.67 & .78 \\
Engineering Program Expectancy & 4.72 & 0.77 & .89 \\
Empowerment & 4.24 & 0.98 & .90 \\
Usefulness & 4.08 & 1.12 & .94 \\
Success & 4.64 & 0.85 & .89 \\
Interest & 4.05 & 1.07 & .93 \\
Caring & 4.98 & 0.78 & .91 \\
\hline
\end{tabular}

Table 4. Descriptive Statistics and Reliabilities of Pilot Group-End of the Semester

\begin{tabular}{llll}
\hline Variables & Mean & $\begin{array}{l}\text { Standard } \\
\text { Deviation }\end{array}$ & $\begin{array}{l}\text { Cronbach's } \\
\text { Alpha }(\alpha)\end{array}$ \\
\hline Major Intention & & 0.87 & .89 \\
Career Intention & 5.41 & 0.81 & .84 \\
Engineering Identification & 5.21 & 0.74 & .89 \\
Engineering Utility & 5.23 & 1.08 & .96 \\
Engineering Program Belonging & 5.25 & 0.69 & .79 \\
Engineering Program Expectancy & 4.98 & 0.67 & .84 \\
Empowerment & 4.82 & 1.00 & .91 \\
Usefulness & 4.20 & 1.15 & .94 \\
Success & 4.08 & 0.91 & .90 \\
Interest & 4.53 & 1.14 & .93 \\
Caring & 3.98 & 0.77 & .91 \\
\hline
\end{tabular}

Table 5. Group Mean Differences between the Two Groups-Beginning of Semester

\begin{tabular}{|c|c|c|c|c|c|c|c|}
\hline \multirow[b]{2}{*}{ Variables } & \multirow[b]{2}{*}{$\begin{array}{l}\text { Traditional } \\
\text { (Mean) }\end{array}$} & \multirow[b]{2}{*}{$\begin{array}{l}\text { Pilot } \\
\text { (Mean) }\end{array}$} & \multirow[b]{2}{*}{$\begin{array}{c}\text { Mean } \\
\text { Differences }\end{array}$} & \multirow[b]{2}{*}{$t$} & \multirow[b]{2}{*}{$p$ (two-tailed) } & \multicolumn{2}{|c|}{$95 \% \mathrm{CI}$} \\
\hline & & & & & & Lower & Upper \\
\hline Major Intention & 5.35 & 5.37 & -.02 & -.28 & .77 & -.14 & .10 \\
\hline Career Intention & 5.08 & 5.08 & .00 & -.03 & .98 & -.14 & .13 \\
\hline $\begin{array}{l}\text { Engineering } \\
\text { Identification }\end{array}$ & 5.24 & 5.22 & .02 & .45 & .65 & -.08 & .13 \\
\hline Engineering Utility & 5.49 & 5.32 & .17 & 2.27 & .02 & .02 & .31 \\
\hline $\begin{array}{l}\text { Engineering } \\
\text { Belonging }\end{array}$ & 4.87 & 4.94 & -.07 & .58 & .56 & -.07 & .13 \\
\hline $\begin{array}{l}\text { Engineering } \\
\text { Expectancy }\end{array}$ & 4.83 & 4.93 & -.10 & -1.89 & .06 & -.21 & .00 \\
\hline
\end{tabular}

Note. $\mathrm{CI}=$ Confidence Interval 
Table 6. Group Mean Differences Between the Two Groups-End of Semester

\begin{tabular}{|c|c|c|c|c|c|c|c|}
\hline \multirow[b]{2}{*}{ Variables } & \multirow[b]{2}{*}{$\begin{array}{l}\text { Traditional } \\
\text { (Mean) }\end{array}$} & \multirow[b]{2}{*}{$\begin{array}{l}\text { Pilot } \\
\text { (Mean) }\end{array}$} & \multirow[b]{2}{*}{$\begin{array}{c}\text { Mean } \\
\text { Differences }\end{array}$} & \multirow[b]{2}{*}{$t$} & \multirow[b]{2}{*}{$p$ (two-tailed $)$} & \multicolumn{2}{|c|}{$95 \%$ CI } \\
\hline & & & & & & Lower & Upper \\
\hline Major Intention & 5.39 & 5.41 & -.02 & -.29 & .77 & -.15 & .11 \\
\hline Career Intention & 5.13 & 5.21 & -.08 & -1.22 & .22 & -.22 & .05 \\
\hline Engineering & 5.17 & 5.23 & -.05 & -.92 & .36 & -.16 & .06 \\
\hline Identification & & & & & & & \\
\hline Engineering Utility & 5.22 & 5.25 & -.03 & -.34 & .73 & -.19 & .13 \\
\hline Engineering & 4.90 & 4.98 & -.08 & -1.62 & .11 & -.19 & .02 \\
\hline Belonging & & & & & & & \\
\hline Engineering & 4.72 & 4.82 & -.10 & -1.94 & .05 & -.21 & .00 \\
\hline Expectancy & & & & & & & \\
\hline Empowerment & 4.24 & 4.20 & .04 & .52 & .60 & -.11 & .19 \\
\hline Usefulness & 4.08 & 4.08 & .00 & .01 & .99 & -.17 & .17 \\
\hline Success & 4.64 & 4.53 & .11 & 1.63 & .10 & -.02 & .24 \\
\hline Interest & 4.05 & 3.98 & .07 & .93 & .36 & -.09 & .24 \\
\hline Caring & 4.98 & 5.09 & -.11 & -1.79 & .07 & -.23 & .01 \\
\hline
\end{tabular}

Note. $95 \%$ confidence interval used

\section{Discussion}

The results of the six inependent sample $t$-tests, at the beginning of the semester, showed that there were no significant differences in the mean scores between the two groups on those six variables except in the case of engineering program utility (see Table 5). This indicates that the two groups were equivalent, especially on those measures collected at the beginning of the semester. Therefore, the lack of differences between the two groups on those 11 constructs at the end of semester indicates that this study failed to detect effectiveness of an active learning approach in enhancing students' motivation at a statistically significant level.

Students were not randomly assigned to the two groups. In the absence of random assignment, it is difficult to determine that the two groups are equivalent in terms of the variables being investigated. However, with a pretest we can guage whether or not the two groups are similar on the measures collected before administering the intervention to the treatment group (Leedy \& Ormrod, 2013). This in turn gives researchers more confidence about any conclusions they would draw from post-treatment results (Pedhazur \& Schmelkin, 1991). The results of this study were inconsistent with the findings of other studies. For example, according to Matusovich et al. (2012), students reported higher perceptions of usefulness when the student-centered instructional techqnique (PBL) was used compared to students who were taught the class using a traditional engineering design (TED) technique. Usefulness is one of the elements of the MUSIC Model. In a similar study, Matusovich et al. (2011) found that students felt more empowered, yet another MUSIC element, when PBL was used as compared to when TED was used. Jones et al. (2013) found that the use of PBL increased students' motivation and other elements of the MUSIC Model.

It is to be noted, however, that the lack of differences between the two groups can be seen as a positive result in the sense that there was no significant decline in the motivational level of students in the pilot group. This was the first implementation of the pilot program; therefore, the program was not fully developed and there was a lot of fluidity. Introduction of any such new programs can have the potential to create uncertainty and dissonance in students. Furthermore, it will not be long before students in the two groups exchange information about the way their classes were taught further worsening dissonance in students. Therefore, it can be argued that this result can be seen as a positive outcome because the new program that was implemented for the first time and even though it was still evolving it did not led to the decline of motivation of students in the pilot group.

\section{Limitations and Future Research}

Four probable causes of these inconsistent findings were identified: (1) intensity of treatment, (2) timing of treatment, (3) length of treatment, and (4) random assignment. The first reason could be the lack of intensity or strength of treatment. The instructional technique used for the pilot group had features of an active learning approach, but was not a full-fledged active learning approach and probably not sufficiently different from the other group. Under such circumstances, it may be difficult to detect if the treatment yielded discernable effects or statistically significant benefits. The second reason relates to the timing of treatment. The data for this study were collected from first year engineering students during their first semester. Therefore, it is possible that students were highly motivated when they first began their undergraduate degree in engineering and their initial motivation level were the same when they completed the survey. The inclusion of senior students in such studies may give a clearer picture of the effectiveness of an active learning approach. The third reason could be the length of treatment. It is possible that a period of one semester may not be sufficient for students to form a strong identity and commitment to engineerng. Additionally, a period of one 
semester may not be sufficient for them to determine whether or not their experiences in engineering are consistent with their initial expectations. The real impact of an active learning approach to emerge may require more than one semester and perhaps a greater intensity of treatment.

\section{Acknowledgment}

The authors would like to thank Virginia Tech's Open Access Subvention Fund for paying the publication fees for this article.

\section{References}

Al-Bahi, A. M. (2006, June). Development of a design phase checklist for outcome based active/cooperative learning. Paper presented at the American Society for Engineering Education's (ASEE) annual conference and exposition. Chicago, IL.

Bernold, L. E., Spurlin, J. E., \& Anson, C. M. (2007). Understanding our students: A longitudinal study of success and failure in engineering with implications for increased retention. Journal of Engineering Education, 96(3), 263-274. https://doi.org/10.1002/j.2168-9830.2007.tb00935.x

Bonewell, C., \& Eison, J. (1991). Active learning: Creating excitement in the classroom. ASHE- ERIC Higher Education Report No 1.Washington, D. C.

Cabrera, A., Colbeck, C., \& Terenzini, P. (1998, November). Teaching for professional competence: Instructional practices that promote development of group problem solving and design skills. Paper presented at the meeting of the Association for the Study of Higher Education, Miami, FL.

Carrico, C., \& Tendhar, C. (2012, June). The use of the Social Cognitive Career Theory model to predict engineering students' motivation in the PRODUCED program. Paper presented at the annual meeting of the American Society for Engineering Education (ASEE), San Antonio, TX.

Felder, R. M., \& Brent, R. (2003). Designing and teaching courses to satisfy the ABET engineering criteria. Journal of Engineering Education, 92(1), 7-25. https://doi.org/10.1002/j.2168-9830.2003.tb00734.x

Felder, R. M., Forrest, K. D., Baker-Ward, L., Dietz, E. J., \& Mohr, P. H. (1993). A longitudinal study of engineering student performance and retention: Success and failure in the introductory course. Journal of Engineering Education, 82(1), 15-21. https://doi.org/10.1002/j.2168-9830.1993.tb00067.x

Gates, Jr., J., \& Mirkin, C. (2012, June). Encouraging STEM students is in the national interest. The Chronicle of Higher Education. Retrieved from http://chronicle.com/article/Encouraging-STEM-Students-Is/132425/

Hoit, M., \& Ohland, M. (1998). Impact of a discipline-based Introduction to engineering course on improving retention. Journal of Engineering Education 87(1): 79-85. https://doi.org/10.1002/j.2168-9830.1998.tb00325.x

Honolulu, H., Major, D. A., Holland, J. M., \& Oborn, K. L. (2012). The Influence of Proactive Personality and Coping on Commitment to STEM Majors. The Career Development Quarterly, 60(1), 16-24. https://doi.org/10.1002/j.2161-0045.2012.00002.x

Jones, B. D. (2009). Motivating students to engage in learning: The MUSIC Model of Academic Motivation. International Journal of Teaching and Learning in Higher Education, 21(2), 272-285.

Jones, B. D. (2010). An examination of motivation model components in face-to-face and online instruction. Electronic Journal of Research in Educational Psychology, 8(3), 915- 944.

Jones, B. D. (2016). User guide for assessing the components of the MUSIC Model of Academic Motivation. Retrieved from http://www.theMUSICmodel.com

Jones, B. D., Epler, C. M., Mokri, P., Bryant, L. H., \& Paretti, M. C. (2013). The effects of a collaborative problem-based learning experience on students' motivation in engineering capstone courses. Interdisciplinary Journal of Problem-Based Learning, 7(2), 34-71. https://doi.org/10.7771/1541-5015.1344

Jones, B. D., Osborne, J. W., Paretti, M. C., \& Matusovich, H. M. (2014). Relationships among students' perceptions of a first-year engineering design course and their engineering identification, motivational beliefs, course efforts, and academic outcomes. International Journal of Engineering Education, 30(6), 1340-1356.

Jones, B. D., Paretti, M. C., Hein, S. F., \& Knott, T. W. (2010). An analysis of motivation constructs with with first-year engineering sttudents: Relationships among expectancies, values, achievements, and career plans. Journal of Engineering Education, 99(4), 319- 336. https://doi.org/10.1002/j.2168-9830.2010.tb01066.x 
Jones, B. D., Tendhar, C., \& Paretti, M. C. (2015). The effects of students' course perceptions on their domain identification, motivational beliefs, and goals. Journal of Career Development, 43(5), 383-397. https://doi.org/10.1177/0894845315603821

Knight, J. D., Fulop, R. M., Marquez-Magana, L., \& Tanner, K. D. (2008). Investigative cases student outcomes in an upper-division cell and molecular biology laboratory course at a minority-serving institution. CBE Life Sciences Education, 7(4), 382-393. https://doi.org/10.1187/cbe.08-06-0027

Leedy, P. D., \& Ormrod, J. E. (2013). Practical research: Planning and Design. Upper Saddle River, NJ: Pearson.

Lichtenstein, G., Loshbaugh, H. G., Claar, B., Bailey, T. L., \& Sheppard, S. (June, 2007). Should I stay or should I go? Engineering students' persistence is based on little experience or data. Paper presented at the annual meeting of the American Society of Engineering Education (ASEE)

Matusovich, H. M., Jones, B. B., Paretti, M. C., Moore, J. P., \& Hunter, D. A. N. (2011, June). Motivating factors in problem-based learning: A student perspective on the role of the facilitator. Paper presented at the annual meeting of the American Society of Engineering Education, Vancouver BC, Canada.

Matusovich, H. M., Paretti, M. C., Jones, B. D., \& Brown, P. R. (2012, June). How problem- based learning and traditional engineering design pedagogies influence the motivation of first-year engineering students. Paper presented at the annual meeting of the American Society for Engineering Education, San Antonio, TX.

Pedhazur, E. J., \& Schmelkin, L. P. (1991). Measurement design, and analysis: An integrated approach. Hillsdale, NJ; Lawrence Erlbaum Associates.

Rollins, J. C. (2011). U.S. Science, Technology, Engineering, and Math (STEM) Education: Education in a Competitive and Globalizing World. New York, NY; Nova Science Seymour, E., \& Hewitt, N. (1997). Talking about leaving: Why undergraduates leave the sciences. Boulder, Colorado: Westview Press.

Springer, L., Stanne, M. E., \& Donovan, S. S. (1999). Effects of small-group learning on undergraduate in science, mathematics, engineering, and technology: A meta-analysis. Review of Educational Research, 69(1), 21-51. https://doi.org/10.3102/00346543069001021

Strenta, A. C., Elliott, R., Adair, R., Matier, M., \& Scott, J. (1994). Choosing and leaving science in highly selective institutions. Research in Higher Education, 35(5), 513-547. https://doi.org/10.1007/BF02497086

Tendhar, C., Paretti, M. C., \& Jones, B. D. (2017). The effects of gender, engineering identification, and engineering program expectancy on engineering career intentions: Applying Hierarchical Linear Modeling (HLM) in engineering education research. American Journal of Engineering Education, 8(2), 157-170. https://doi.org/10.19030/ajee.v8i2.10072

Tendhar, C., Singh, K., \& Jones, B. D. (2018). Using the domain identification model to study major and career decision making process. European Journal of Engineering Education, 43(2), 234-246. https://doi.org/10.1080/03043797.2017.1329280

Watkins, J., \& Mazur, E. (2013). Retaining students in Science, Technology, Engineering, and Mathematics (STEM) majors. Journal of College Science Teaching, 42(5), 36-41.

Weiss, T. (2009, June 3). The 10 hardest jobs to fill in America. Forbes.com. Retrieved from http://www.forbes.com

\section{Copyrights}

Copyright for this article is retained by the author(s), with first publication rights granted to the journal.

This is an open-access article distributed under the terms and conditions of the Creative Commons Attribution license which permits unrestricted use, distribution, and reproduction in any medium, provided the original work is properly cited. 